\title{
Pseudonocardia parietis sp. nov., from the indoor environment
}

\author{
Correspondence \\ P. Kämpfer \\ peter.kaempfer@umwelt.uni- \\ giessen.de
}

\author{
J. Schäfer, ${ }^{1}$ H.-J. Busse ${ }^{2}$ and P. Kämpfer ${ }^{1}$ \\ ${ }^{1}$ Institut für Angewandte Mikrobiologie, Justus-Liebig-Universität Giessen, D-35392 Giessen, \\ Germany \\ ${ }^{2}$ Institut für Bakteriologie, Mykologie und Hygiene, Veterinärmedizinische Universität, A-1210 Wien, \\ Austria
}

\begin{abstract}
A Gram-positive, rod-shaped, non-endospore-forming, mycelium-forming actinobacterium (04St- $002^{\top}$ ) was isolated from the wall of an indoor environment colonized with moulds. On the basis of $16 \mathrm{~S}$ rRNA gene sequence similarity studies, strain $04-\mathrm{St}-002^{\top}$ was shown to belong to the family Pseudonocardiaceae, and to be most closely related to Pseudonocardia antarctica (99.2\%) and Pseudonocardia alni (99.1\%). The major menaquinones were MK-8( $\left.\mathrm{H}_{4}\right)$ and MK$8\left(\mathrm{H}_{2}\right)$, the phospholipid type was PIII, and the polar lipid profile consisted of the major lipids diphosphatidylglycerol, phosphatidylmonomethylethanolamine and phosphatidylcholine. Moderate amounts of phosphatidylglycerol and an unknown polar lipid, L1, small or trace amounts of phosphatidylinositol, phosphatidylinositol-mannoside, three unknown lipids, two unknown phospholipids and four unknown glycolipids were also detected. The major fatty acids iso- $\mathrm{C}_{16: 0 \text {, }}$ iso- $\mathrm{C}_{16: 1}, \mathrm{C}_{16: 0}$ and $\mathrm{C}_{16: 1} \omega 7 \mathrm{c}$ supported the affiliation of strain $04-\mathrm{St}-002^{\top}$ to the genus Pseudonocardia. The results of DNA-DNA hybridization, and physiological and biochemical tests allowed genotypic and phenotypic differentiation of strain $04-\mathrm{St}-002^{\top}$ from the two most closely related species, $P$. alni and $P$. antarctica. Strain $04-S t-002^{\top}$ represents a novel species, for which the name Pseudonocardia parietis sp. nov. is proposed. The type strain is $04-\mathrm{St}-002^{\top}$ (=DSM $45256^{\top}=$ CCM $7582^{\top}$ ).
\end{abstract}

The genus Pseudonocardia, originally proposed by Henssen (1957) for nocardioform actinomycetes that lack mycolate and have a type IV cell wall, reflected by the presence of meso-diaminopimelic acid and the sugars arabinose and galactose (Lechevalier \& Lechevalier, 1980), comprises 28 species at the time of writing (Gu et al., 2006; Huang et al., 2002; Lee et al., 2000, 2001, 2002, 2004; Kämpfer \& Kroppenstedt, 2004; Liu et al., 2006; Mahendra \& AlvarezCohen, 2005; Qin et al., 2008).

Strain $04-$ St $-002^{\mathrm{T}}$ was isolated from a wall colonized with moulds. After extraction of $1 \mathrm{~g}$ material sample for $15 \mathrm{~min}$ in $10 \mathrm{ml} 0.9 \% \mathrm{NaCl}$ solution containing $0.01 \%(\mathrm{v} / \mathrm{v})$ Tween 80 and dilution on M79 agar (containing $10 \mathrm{~g}$ glucose, $10 \mathrm{~g}$ Bacto peptone, $2 \mathrm{~g}$ casein hydrolysate, $2 \mathrm{~g}$ yeast extract, $6 \mathrm{~g} \mathrm{NaCl}, 15 \mathrm{~g}$ agar) for 2 weeks at $28{ }^{\circ} \mathrm{C}$, the strain was maintained on M79 at $28{ }^{\circ} \mathrm{C}$ and showed a brown-coloured substrate mycelium. After a few days, a white aerial mycelium formed.

Morphological properties, Gram-staining and cell morphology were observed by phase-contrast microscopy as described by Kämpfer \& Kroppenstedt (2004). DNA

The GenBank/EMBL/DDBJ accession number for the 16S rRNA gene sequence of strain $04-\mathrm{St}_{-002}{ }^{\top}$ is FM863703. isolation was performed with a commercial DNA extraction kit (GenElute Plant Genomic DNA kit; Sigma). Initially, the sample was prepared by a $1 \mathrm{~min}$ bead-beating step with 1 g 0.1 diameter Zirconia beads.

Multiple sequence alignment and analysis of the data were performed using the software package MEGA version 4 (Tamura et al., 2007). Genetic distance calculations (distance options according to the Kimura two-parameter model), and clustering with the neighbour-joining (Fig. 1) and maximum-parsimony methods (results not shown) was performed by using bootstrap values based on 1000 replications. The $16 \mathrm{~S}$ rRNA gene sequence of strain 04-St$002^{\mathrm{T}}$ was a continuous stretch of $1407 \mathrm{bp}$. Sequence similarity calculations after a neighbour-joining analysis indicated that the closest relatives of strain $04-\mathrm{St}-002^{\mathrm{T}}$ were Pseudonocardia antarctica DSM 44749 ${ }^{\mathrm{T}} \quad(99.2 \%)$, Pseudonocardia alni DSM $44104^{\mathrm{T}} \quad(99.1 \%)$ and Pseudonocardia carboxydivorans SWP-2006 ${ }^{\mathrm{T}}$ (99.1\%). Lower sequence similarities were found with all other described species of the genus Pseudonocardia.

For quinone and polar lipid analyses, cells were grown in PYE medium $(0.3 \%$ peptone from casein, $0.3 \%$ yeast extract, $\mathrm{pH}$ 7.2). Extraction of menaquinones was done as described by Tindall (1990a) and Altenburger et al. (1996), 


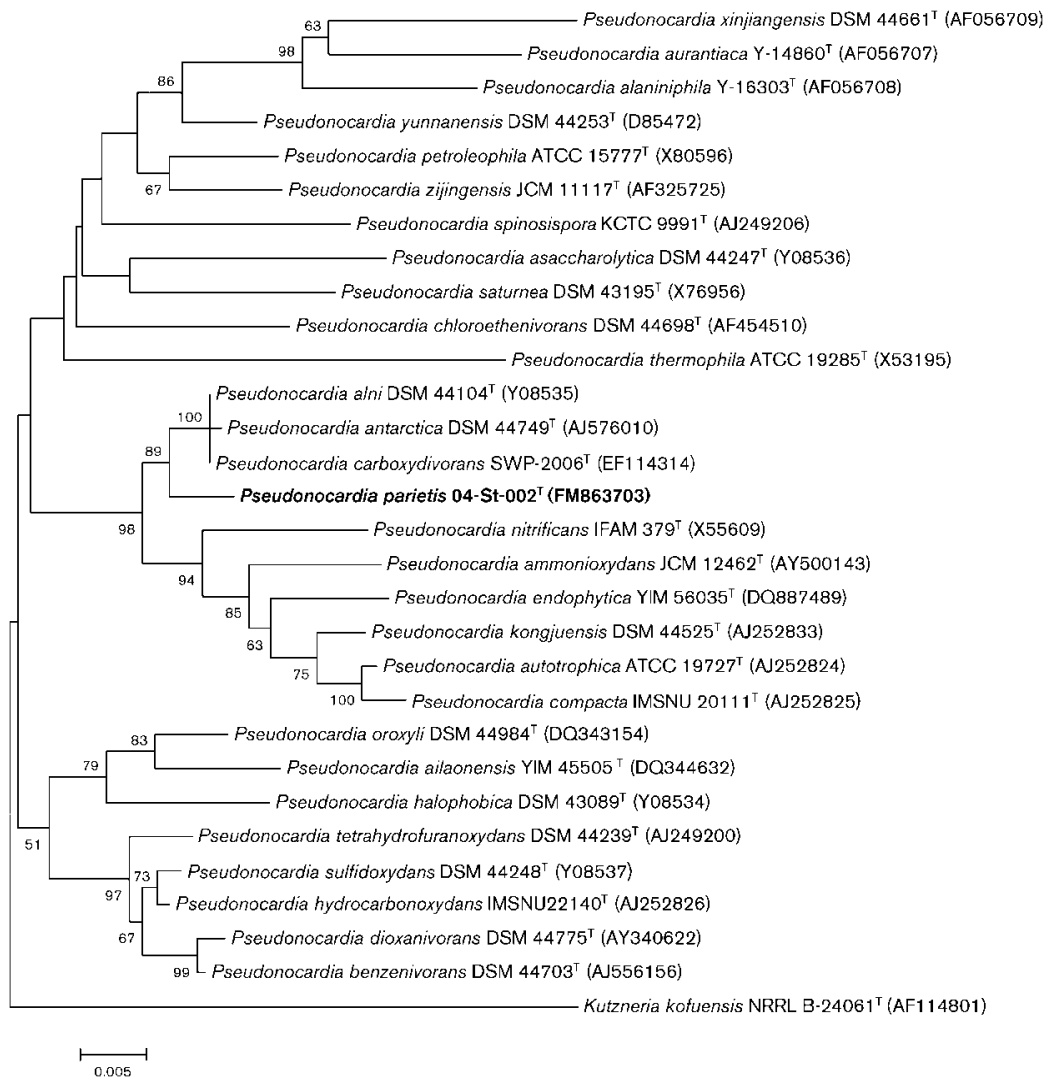

Fig. 1. Phylogenetic analysis based on $16 \mathrm{~S}$ rRNA gene sequences available from the EMBL database (accession numbers are given in parentheses). Multiple alignment, distances calculations (distance options according to the Kimura's two-parameter model) and clustering using the neighbour-joining method were performed by using the software package MEGA version 4 (Tamura et al., 2007). Bootstrap values based on 1000 replications are listed as percentages at the branching points. Bar, 0.005 substitutions per nucleotide position.

and analysed by HPLC according to Stolz et al. (2007); extraction and analysis of polar lipids was as described by Tindall (1990b). Strain 04-St-002 ${ }^{\mathrm{T}}$ exhibited a quinone system with the predominant compounds menaquinones MK- $8\left(\mathrm{H}_{4}\right)(73 \%)$ and MK-8 $\left(\mathrm{H}_{2}\right)(20 \%)$. Minor amounts $(<2 \%)$ of MK-7, MK-7 $\left(\mathrm{H}_{2}\right)$, MK-8, MK-9, MK-9 $\left(\mathrm{H}_{2}\right)$ and MK-9 $\left(\mathrm{H}_{4}\right)$ were also detected.

The polar lipid profile was rather complex, consisting of 16 components (Fig. 2). Major lipids were diphosphatidylglycerol, phosphatidylmonomethylethanolamine and phosphatidylcholine. Furthermore, moderate amounts of phosphatidylglycerol, an unknown lipid, L1, and small or trace amounts of phosphatidylinositol, phosphatidylinositol-mannoside, three unknown lipids, two unknown phospholipids and four unknown glycolipids were detected. The presence of phosphatidylcholine attributes phospholipid type PIII to strain 04-St- $002^{\mathrm{T}}$ (Lechevalier et al., 1977) which has been reported for several Pseudonocardia species, including Pseudonocardia compacta, P. alni, P. antarctica, Pseudonocardia ammonioxydans, Pseudonocardia kongjuensis and Pseudonocardia spinosispora (Henssen et al., 1983; Evtushenko et al., 1989; Lee et al., 2001, 2002; Prabahar et al., 2004; Liu et al., 2006). Another species, Pseudonocardia ailaonensis, for which phospholipid type PIII was reported might be erroneously allocated to this phospholipid type because the authors did not report the presence of phosphatidylcholine (Qin et al., 2008). However, this lipid profile is most

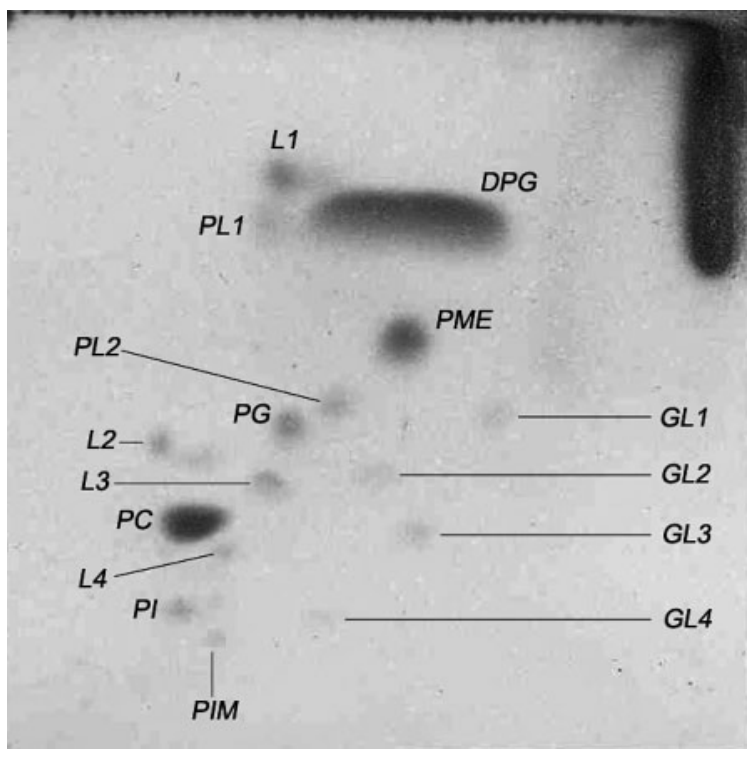

Fig. 2. Polar lipid profile of $04-\mathrm{St}-002^{\top}$ after two-dimensional TLC and detection with molybdatophosphoric acid. Abbreviations: PME, phosphatidylmonomethylethanolamine; PG, phosphatidylglycerol; DPG, diphosphatidylglycerol; PC, phosphatidylcholine; PI, phosphatidylinositol; PIM, phosphatidylinositol-mannoside; PL1, 2, unknown phospholipids; L1-4, unknown polar lipids; GL1-4, unknown glycolipids. First dimension, left to right; second dimension bottom to top. 
Table 1. Physiological characteristics of the type strains of Pseudonocardia species

Taxa: $1,04-S t-002^{\mathrm{T}} ; 2$, P. alni DSM $44104^{\mathrm{T}} ; 3$, P. antarctica DSM $44749^{\mathrm{T}}$; 4, P. carboxydivorans $\mathrm{Y}^{\mathrm{T}}$ (data from Park et al., 2008). +, Positive; - , negative; $(+)$, weakly positive; ND, not detected.

\begin{tabular}{|c|c|c|c|c|}
\hline Utilization test & 1 & 2 & 3 & 4 \\
\hline$N$-Acetyl-D-glucosamine & $(+)$ & + & + & + \\
\hline Cellobiose & - & + & $(+)^{*}$ & - \\
\hline D-Fructose & + & $+\dagger$ & $+^{*}$ & - \\
\hline D-Galactose & $(+)$ & $(+) \dagger$ & $+^{*}$ & - \\
\hline meso-Inositol & - & - & $-{ }^{*}$ & - \\
\hline Inulin & $\mathrm{ND}$ & ND & ND & + \\
\hline Maltose & + & $+\dagger$ & $+^{*}$ & - \\
\hline Mannan & ND & ND & ND & + \\
\hline D-Mannitol & + & + & $+^{*}$ & - \\
\hline D-Mannose & $(+)$ & $+\dagger$ & $+^{*}$ & - \\
\hline L-Rhamnose & - & - & $-\ddagger$ & - \\
\hline D-Ribose & - & $(+) \dagger$ & - & - \\
\hline Sorbitol & + & $+\dagger$ & + & - \\
\hline Sucrose & + & $+\dagger$ & + & - \\
\hline Trehalose & $(+)$ & $+\dagger$ & $+^{*}$ & - \\
\hline D-Xylose & - & $+\dagger$ & $+^{*}$ & - \\
\hline
\end{tabular}

${ }^{*}, \dagger$ Data congruent with those reported by Prabahar et al. (2004) and Evtushenko et al. (1989).

$\ddagger$ Data not congruent with those reported by Prabahar et al. (2004).

similar to that reported for close relative $P$. alni (Evtushenko et al., 1989, Warwick et al. 1994), whereas the other close relative, $P$. antarctica, contains phosphatidylethanolamine, distinguishing it from $04-\mathrm{St}-002^{\mathrm{T}}$ (Prabahar et al., 2004). The presence of phosphatidylinositol-mannoside has not been reported for either of these two species.

Fatty acid analysis was performed according to Kämpfer \& Kroppenstedt (1996). The fatty acid profile of strain 04-St$002^{\mathrm{T}}$ was very similar to those of the other closely related species, $P$. alni and P. antarctica, and was congruent with the fatty acid profiles reported by Reichert et al. (1998).

Results of the comparative physiological characterization using identical test conditions are given in Table 1 and the species description, using methods described previously (Kämpfer et al., 1991). DNA-DNA hybridization experiments were performed with $04-\mathrm{St}-002^{\mathrm{T}}$ and the type strains of $P$. alni and $P$. antarctica using the method described by Ziemke et al. (1998), except that for nick translation, $2 \mu \mathrm{g}$ of DNA was labelled during a $3 \mathrm{~h}$ incubation at $15{ }^{\circ} \mathrm{C}$. Strain $04-S t-002^{\mathrm{T}}$ showed a relatively low DNA-DNA similarity to $P$. alni DSM $44104^{\mathrm{T}}(44.5 \%$, reciprocal $34.9 \%)$, and P. antarctica DSM $44749^{\mathrm{T}}(44.1 \%$, reciprocal $30.5 \%)$. The observed physiological differences between these type strains (Table 1) clearly warrant the creation of a separate species.
Table 2. Major fatty acid composition (\%) of type strains of species of the genus Pseudonocardia related to strain 04-St$002^{\top}$

Taxa: 1, 04-St-002 ${ }^{\mathrm{T}}$; 2, P. alni DSM $44104^{\mathrm{T}}$ (this study; Kämpfer \& Kroppenstedt, 2004); 3, P. antarctica DSM $44749^{\mathrm{T}}$ (this study; Kämpfer \& Kroppenstedt, 2004); 4, P. carboxydivorans $\mathrm{Y}^{\mathrm{T}}$ (data from Park et al., 2008). All strains were grown under the same conditions prior to fatty acid analysis.

\begin{tabular}{|c|c|c|c|c|}
\hline Fatty acid & 1 & 2 & 3 & 4 \\
\hline \multicolumn{5}{|l|}{ Saturated fatty acid: } \\
\hline $\mathrm{C}_{15: 0}$ & 0.5 & & & \\
\hline $\mathrm{C}_{16: 0}$ & 3.2 & 12.4 & 6.2 & 1.4 \\
\hline$C_{17: 0}$ & 0.6 & 2.0 & & \\
\hline \multicolumn{5}{|c|}{ Unsaturated fatty acids*: } \\
\hline $\mathrm{C}_{15: 1}$ & & & & 0.9 \\
\hline $\mathrm{C}_{15: 1} \omega 6 c$ & 0.5 & & & \\
\hline $\mathrm{C}_{17: 1} \omega 8 c$ & 1.7 & 3.0 & 2.6 & 2.4 \\
\hline \multicolumn{5}{|l|}{ Branched fatty acids: } \\
\hline iso- $\mathrm{C}_{14: 0}$ & 1.6 & & 1.3 & 1.9 \\
\hline iso- $\mathrm{C}_{15: 0}$ & 1.0 & 7.7 & 7.5 & 5.0 \\
\hline iso- $\mathrm{C}_{16: 0}$ & 63.6 & 34.5 & 41.4 & 47.2 \\
\hline iso- $\mathrm{C}_{17: 0}$ & 1.4 & 7.3 & 7.0 & 3.0 \\
\hline iso- $\mathrm{C}_{18: 0}$ & 0.7 & & & \\
\hline iso- $\mathrm{C}_{16: 1} \mathrm{H}$ & 16.9 & 5.3 & 6.8 & 22.8 \\
\hline anteiso- $\mathrm{C}_{15: 0}$ & & & & 0.6 \\
\hline anteiso- $\mathrm{C}_{17: 0}$ & 1.0 & 7.9 & 10.3 & 2.6 \\
\hline $\mathrm{C}_{16: 0} 10$-methyl & 2.0 & 6.9 & 6.4 & 4.6 \\
\hline $\mathrm{C}_{17: 0}$ 10-methyl & 1.9 & & 1.6 & 1.5 \\
\hline Summed feature $3 \dagger$ & 3.2 & 12.9 & 8.6 & 5.9 \\
\hline
\end{tabular}

${ }^{*}$ For unsaturated fatty acids, the position of the double bond is located by counting from the methyl $(\omega)$ end of the carbon chain; $c$ indicates the cis isomers.

$\dagger$ Summed features are groups of two or three fatty acids that cannot be separated by GLC with the MIDI system. Summed feature 3 contains one or more of the fatty acids $\mathrm{C}_{16: 1} \omega 7 c$ and $\mathrm{C}_{15: 0}$ iso 2-OH.

\section{Description of Pseudonocardia parietis sp. nov.}

Pseudonocardia parietis (pa.ri'e.tis. L. gen. n. parietis of the wall of a house).

Forms branched mycelia-like filaments, about $1.3 \mu \mathrm{m}$ in width. Single spore-like bodies are observed at the end of the cells. Aerial mycelium on agar is white, branched and becomes fragmented. Gram-positive, oxidase-positive, catalase-positive, showing an oxidative metabolism. Good growth occurs after 3 days incubation on R2A agar and nutrient agar at 25$30{ }^{\circ} \mathrm{C}$. Quinone system is composed of the major compounds menaquinone MK-8 $\left(\mathrm{H}_{4}\right)$ and MK-8 $\left(\mathrm{H}_{2}\right)$. Phospholipid type is PIII. Polar lipid profile consists of the major lipids diphosphatidylglycerol, phosphatidylmonomethylethanolamine and phosphatidylcholine. Moderate amounts of phosphatidylglycerol and an unknown polar lipid L1, small or trace amounts of phosphatidylinositol, phosphatidylinositol-mannoside, three unknown lipids, two unknown phospholipids and four unknown glycolipids are also detectable. Major fatty 
acids are iso-branched hexadecanoates. Small to moderate amounts of methyl-branched fatty acids ( $\mathrm{C}_{16: 0}$ 10-methyl, $\mathrm{C}_{17: 0}$ 10-methyl) are detected (Table 2). Carbon source utilizations (including differentiating characters under identical conditions) are indicated in Table 1.

Isolated in Stuttgart, Germany, sampled from the wall of a house colonized with moulds. Type strain is $04-\mathrm{St}-002^{\mathrm{T}}$ $\left(=\right.$ DSM $45256^{\mathrm{T}}=$ CCM $\left.7582^{\mathrm{T}}\right)$.

\section{Acknowledgements}

We are grateful to Gundula Will for excellent technical assistance and Jean Euzéby for support with the nomenclature. The study was supported in part by the Federal Environment Agency (Umweltbundesamt), grant number FKZ 20562236.

\section{References}

Altenburger, P., Kämpfer, P., Makristathis, A., Lubitz, W. \& Busse, H.-J. (1996). Classification of bacteria isolated from a medieval wall painting. J Biotechnol 47, 39-52.

Evtushenko, L. I., Akimov, V. N., Dobritsa, S. V. \& Taptykova, S. D. (1989). A new species of actinomycete, Amycolata alni. Int J Syst Bacteriol 39, 72-77.

Gu, Q., Luo, H., Zheng, W., Liu, Z. \& Huang, Y. (2006). Pseudonocardia oroxyli sp. nov., a novel actinomycete isolated from surface-sterilized Oroxylum indicum root. Int J Syst Evol Microbiol 56, 2193-2197.

Henssen, A. (1957). Beiträge zur Morphologie und Systematik der thermophilen Actinomyceten. Arch Mikrobiol 26, 373-414.

Henssen, A., Happach-Kasan, C., Renner, B. \& Vobis, G. (1983). Pseudonocardia compacta sp. nov. Int J Syst Bacteriol 33, 829-836.

Huang, Y., Wang, L., Lu, Z., Hong, L., Liu, Z., Tan, G. Y. A. \& Goodfellow, M. (2002). Proposal to combine the genera Actinobispora and Pseudonocardia in an emended genus Pseudonocardia, and description of Pseudonocardia zijingensis sp. nov. Int J Syst Evol Microbiol 52, 977-982.

Kämpfer, P. \& Kroppenstedt, R. M. (1996). Numerical analysis of fatty acid patterns of coryneform bacteria and related taxa. Can J Microbiol 42, 989-1005.

Kämpfer, P. \& Kroppenstedt, R. M. (2004). Pseudonocardia benzenivorans sp. nov. Int J Syst Evol Microbiol 54, 749-751.

Kämpfer, P., Steiof, M. \& Dott, W. (1991). Microbiological characterization of a fuel-oil contaminated site including numerical identification of heterotrophic water and soil bacteria. Microb Ecol 21, 227-251.

Lechevalier, M. P. \& Lechevalier, H. A. (1980). The chemotaxonomy of actinomycetes. In Actinomycete Taxonomy, Special Publication 6, pp. 227-291. Arlington, VA: Society for Industrial Microbiology.

Lechevalier, M. P., De Bièvre, C. \& Lechevalier, H. A. (1977). Chemotaxonomy of aerobic actinomycetes: phospholipid composition. Biochem Syst Ecol 5, 249-260.
Lee, S. D., Kim, E. S. \& Hah, Y. C. (2000). Phylogenetic analysis of the genera Pseudonocardia and Actinobispora based on 16S ribosomal DNA sequences. FEMS Microbiol Lett 182, 125-129.

Lee, S. D., Kim, E. S., Min, K.-L., Lee, W. Y., Kang, S.-O. \& Hah, Y. C. (2001). Pseudonocardia kongjuensis sp. nov., isolated from a gold mine cave. Int J Syst Evol Microbiol 51, 1505-1510.

Lee, S. D., Kim, E. S., Kang, S.-O. \& Hah, Y. C. (2002). Pseudonocardia spinosispora sp. nov., isolated from Korean Soil. Int J Syst Evol Microbiol 52, 1603-1608.

Lee, S.-B., Strand, S. E., Strensel, H. D. \& Herwig, R. P. (2004). Pseudonocardia chloroethenivorans sp. nov., a chloroethene-degrading actinomycete. Int J Syst Evol Microbiol 54, 131-139.

Liu, Z.-P., Wu, J.-F., Liu, Z. H. \& Liu, S.-J. (2006). Pseudonocardia ammonioxydans sp. nov., isolated from coastal sediment. Int J Syst Evol Microbiol 56, 555-558.

Mahendra, S. \& Alvarez-Cohen, L. (2005). Pseudonocardia dioxanivorans sp. nov., a novel actinomycete that grows on 1,4-dioxane. Int $J$ Syst Evol Microbiol 55, 593-598.

Park, S. W., Park, S. T., Lee, J. E. \& Kim, Y. M. (2008). Pseudonocardia carboxydivorans sp. nov., a carbon monoxide-oxidizing actinomycete, and an emended description of the genus Pseudonocardia. Int J Syst Evol Microbiol 58, 2475-2478.

Prabahar, V., Dube, S., Reddy, G. S. N. \& Shivaji, S. (2004). Pseudonocardia antarctica sp. nov., an Actinomycetes from McMurdo Dry Valleys, Antarctica. Syst Appl Microbiol 27, 66-71.

Qin, S., Su, Y.-Y., Zhang, Y.-O., Wang, H.-B., Jiang, C.-L., Xu, L.-H. \& Li, W.-J. (2008). Pseudonocardia ailaonensis sp. nov., isolated from soil in China. Int J Syst Evol Microbiol 58, 2086-2089.

Reichert, K., Lipski, A., Pradella, S., Stackebrandt, E. \& Altendorf, K. (1998). Pseudonocardia asaccharolytica sp. nov. and Pseudonocardia sulfidoxydans sp. nov., two new dimethyl disulfide-degrading actinomycetes and emended description of the genus Pseudonocardia. Int J Syst Bacteriol 48, 441-449.

Stolz, A., Busse, H.-J. \& Kämpfer, P. (2007). Pseudomonas knackmussii sp. nov. Int J Syst Evol Microbiol 57, 572-576.

Tamura, K., Dudley, J., Nei, M. \& Kumar, S. (2007). MEGA4: Molecular Evolutionary Genetics Analysis (MEGA) software version 4.0. Mol Biol Evol 24, 1596-1599.

Tindall, B. J. (1990a). Lipid composition of Halobacterium lacusprofundi. FEMS Microbiol Lett 66, 199-202.

Tindall, B. J. (1990b). A comparative study of the lipid composition of Halobacterium saccharovorum from various sources. Syst Appl Microbiol 13, 128-130.

Warwick, S., Bowen, T., McVeigh, H. P. \& Embley, T. M. (1994). A phylogenetic analysis of the family Pseudonocardiaceae and the genera Actinokineospora and Saccharothrix with 16S rRNA sequences and a proposal to combine the genera Amycolata and Pseudonocardia in an emended genus Pseudonocardia. Int J Syst Bacteriol 44, 293299.

Ziemke, F., Höfle, M. G., Lalucat, J. \& Rosselló-Mora, R. (1998). Reclassification of Shewanella putrefaciens Owen's genomic group II as Shewanella baltica sp. nov. Int J Syst Bacteriol 48, 179-186. 